\title{
Evaluation of Construction
}

Safety in DOE Course Taught in Livermore, California

August 17 - August 20, 1992

E. C. Handwerk

December 1992

Prepared for the U.S. Department of Energy under Contract DE-AC06-76RLO 1830

Pacific Northwest Laboratory Operated for the U.S. Department of Energy by Battelle Memorial Institute

\section{* Battelle}




\title{
DISCLAIMER
}

This report was prepared as an account of work sponsored by an agency of the United States Government. Neither the United States Government nor any agency thereof, nor Battelle Memorial Institute, nor any of their employees, makes any warranty, expressed or implied, or assumes any legal liability or responsibility for the accuracy, completeness, or usefulness of any information, apparatus, product, or process disclosed, or represents that its use would not infringe privately owned rights. Reference herein to any specific commercial product, process, or service by trade name, trademark, manufacturer, or otherwise does not necessarily constitute or imply its endorsement, recummendation, or favoring by the United States Government or any agency thereof, or Battelle Memorial Institute. The views and opinions of authors expressed herein do not necessarily state or refilect those of the United States Government or any agency thereof.

\author{
PACIFIC NORTHWEST LABORATORY \\ operated by \\ BATTELLE MEMORIAL INSTITUTE \\ for the \\ UNITED STATES DEPARTMENT OF ENERGY \\ under Contract DE-AC06-76RLO 1830
}

Printed in the United States of America

Available to DOE and DOE contractors from the

Office of Scientific and Technical Information, P.O. Box 62, Oak Ridge, IN 37831; prices available from (615) 576-8401. FTS 626-8401.

Available to the public from the National Technical Information Service,
U.S. Department of Commerce, 5285 rort Royal Rd., Springfield, VA 22161 . 
EVALUATION OF CONSTRUCTION SAFETY IN DOE COURSE TAUGHT IN LIVERMORE, CALIFORNIA AUGUST 17 TO AUGUST 20, 1992

\author{
E. C. Handwerk
}

December 1992

\title{
Prepared for
}

the U.S. Department of Energy

under Contract DE-AC06-76RLO 1830

Pacific Northwest Laboratory

Richl and, Washington 99352

MASTER 


\subsection{SUMMARY}

This section summarizes trainee evaluations for the Safety and Health Training Section course, "Construction Safety in DOE", which was conducted on August 17-20 for the San Francisco DOE Office, and taught in Livermore, California.

Section 1.1 and 1.2 of this report summarize the quantitative course evaluations that trainees provided upon completion of the course. Appendix $A$ provides a transcript of the trainees' written comments.

Numeric course ratings were generally positive and show that the course material and instruction were very effective. Written comments supported the positive numeric ratings. The course content and knowledge gained by the trainees exceeded most of the students' expectations of the course.

Results from the final examination showed that students gained significant knowledge from the course.

We again had a problem with the site selected for teaching the course. It was taught in one of three adjoining rooms of a Holiday Inn in Livermore, California. The room was small and lighting was poor. Additional problems arose from hotel blocked exits, construction adjacent to the exits, small narrow tables for students, ants everywhere and then fumigation of the room over lunch leaving telltale odor thresholds and general lack of cooperation on the part of the hotel management staff. We are doing everything we can to encourage site sponsors to provide better facilities, that are more conducive to teaching. 


\section{CONTENTS}

1.0 SUMMARY

1.1 SUMMARY OF TRAINEE COURSE EVALUATIONS . . . . . . . . 1.1

1.2 NUMERIC RATINGS . . . . . . . . . . . . . . 1.1

1.3 WRITTEN COMMENTS . . . . . . . . . . . . . . 1.5

1.4 EXAMINATION RESULTS . . . . . . . . . . . . . 1.5

APPENDIX A - EVALUATION COMMENTS . . . . . . . . . . . A.1

APPENDIX B - TRAINEE EVALUATION FORM ............. B.1 


\subsection{SUMMARY OF TRAINEE COURSE EVALUATION}

This course was conducted for San Francisco DOE, in Livermore, California, August 17-20, 1992. Edward Handwerk and Peter Cucuz presented the course to twenty DDE San Francisco, Lawrence Berkeley Laboratory, and DOE Albuquerque personnel.

\subsection{NUMERIC RATINGS}

Fourteen trainees completed a course evaluation form upon finishing the course. The first rating area of the form covered five items dealing with course content; the second rating area covered one item dealing with testing materials; and the third rating area covered thirteen items specifically associated with course topic areas.

For the first and second rating areas, respondents were instructed to rate the degree to which they agreed or disagreed with each statement using a five-point scale with 1 (low) anchored to "strongly disagree" and 5 (high) anchored to "strongly agree". The ratings are as follows:

\section{COLIRSE CONTENT AND TESTING MATERIALS RATINGS}

1. Developed specific skills and competencies in occupational safety compliance that I can use on the job.

Average Class Rating - $\underline{4.60}$

2. Gained a greater understanding of 29 CFR 1926, Safety and Health Regulations for Construction.

Average Class Rating - $\underline{4.80}$

3. Gained factual knowledge about Federal safety and health program requirements related to Construction. 
Average Class Rating - $\underline{4.73}$

4. Would recommend this course to others.

Average Class Rating - $\underline{4.87}$

5. Compliance knowledge gained from this course will make work environments safer.

Average Class Rating - $\underline{4.40}$

6. The final test was a good measure of the knowledge gained in the course. Average Class Rating - $\underline{4.20}$

The average class rating for the course content area and testing materials area was 4.60 . This high rating reinforces the applicability of the course content to the trainees' interests and work environments.

The third rating area asked the respondents to rate the value of each of the fifteen topic areas using a five-point scale with 1 (Unsatisfactory), 2 (Satisfactory), 3 (Good), 4 (Very Good), or 5 (Excellent). The following are the average class ratings that dealt with topic content as well as with the value of the instructor:

\begin{tabular}{||l|l|c|c||}
\hline \multicolumn{1}{|c|}{ INSTRUCTOR } & \multicolumn{1}{|c|}{ TOPICAL AREAS PRESENTED } & CONTENT & INSTRUCT \\
\hline Edward Handwerk & $\begin{array}{l}\text { Introduction to DOE Safety and } \\
\text { Health Programs }\end{array}$ & 4.07 & 4.38 \\
\hline Edward Handwerk & General Interpretations & 4.14 & 4.54 \\
\hline Peter Cucuz & $\begin{array}{l}\text { General Safety and Health } \\
\text { Provisions }\end{array}$ & 4.21 & 4.46 \\
\hline Peter Cucuz & Scaffolding & 4.57 & 4.54 \\
\hline Edward Handwerk & Floor and Wall Openings & 4.36 & 4.46 \\
\hline Edward Handwerk & Ladders & 4.43 & 4.38 \\
\hline Peter Cucuz & Electrical & 4.31 & 4.58 \\
\hline Edward Handwerk & $\begin{array}{l}\text { Power Transmission and } \\
\text { Distribution }\end{array}$ & 3.82 & 4.36 \\
\hline Edward Handwerk & $\begin{array}{l}\text { Materials Handling, Storage, Use } \\
\text { and Disposal }\end{array}$ & 4.36 & 4.38 \\
\hline
\end{tabular}




\begin{tabular}{||l|l|c|c||}
\hline Peter Cucuz & $\begin{array}{l}\text { Cranes, Derricks, Hoists, } \\
\text { Elevators and Conveyors }\end{array}$ & 4.71 & 4.54 \\
\hline Edward Handwerk & $\begin{array}{l}\text { Motor Vehicles, Mechanized } \\
\text { Equipment and Marine Operations }\end{array}$ & 4.14 & 4.46 \\
\hline Edward Handwerk & $\begin{array}{l}\text { Rollover Protect ive Structures, } \\
\text { Overhead Protection }\end{array}$ & 4.36 & 4.62 \\
\hline Peter Cucuz & Hand and Power Tools & 4.43 & 4.62 \\
\hline Edward Handwerk & Welding and Cutting & 4.00 & 4.36 \\
\hline Peter Cucuz & Concrete and Masonry Construction & 4.50 & 4.50 \\
\hline Edward Handwerk & Fire Protection and Prevention & 4.18 & 4.45 \\
\hline Peter Cucuz & Steel Erection & 4.33 & 4.33 \\
\hline Edward Handwerk & Demolition & 4.33 & 4.18 \\
\hline Edward Handwerk & $\begin{array}{l}\text { Occupational Health and } \\
\text { Environmental Control/HazMat }\end{array}$ & 4.10 & 4.30 \\
\hline Edward Handwerk & Personal Protective Equipment & 4.25 & 4.36 \\
\hline Peter Cucuz & Signs, Signals and Barricacles & 4.13 & 4.33 \\
\hline
\end{tabular}

The overall average class rating for topic content was 4.25 . The overall average class rating for instructors was 4.42 . The overall average class rating for E.C. Handwerk was 4.40, for Peter Cucuz the rating was 4.47.

\subsection{WRITTEN COMMENTS}

After providing numeric course evaluations, participants provided written comments about the course. Written comments were transcribed and are presented verbatim in Appendix $A$.

\section{Expectations}

The majority of students felt the course was beneficial and educational based upon the content and the instructors abilities to convey the subject matter. 


\section{Most Helpful Topics}

Scaffolding again led the way as the most helpful topic. This is partly due to scaffolding setup on the outside of our hotel during the week of the class.

\section{Suggestions For Improvement}

The overhead was difficult to see due to the size and lighting in this room. The newer panels recently purchased should bring up the quality of our overhead lightshow. DOE interpretations, where applicable from a headquarters standpoint, will be included for each subpart and addressed by the instructors in the FY93 course revisions.

\subsection{EXAMINATION RESULTS}

On the last day of the course, a final examination was administered to seventeen attendees. There were 25 questions all which were multiple choice questions. The scores ranged from $60 \%$ to $96 \%$ with the average score being 89\%. Sixteen persons successfully completed the class. 


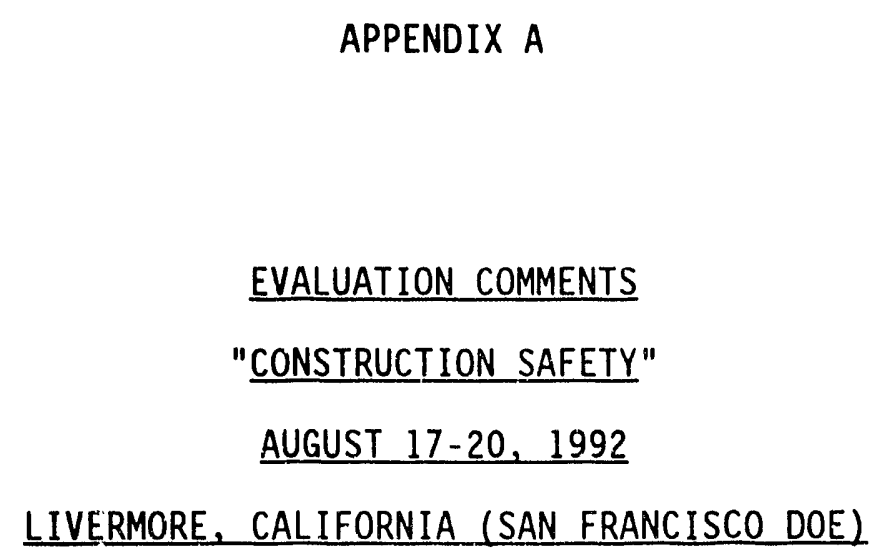


APPENDIX A

TRAINEE EVALUATION RESPONSES

CONSTRUCTION SAFETY"

AUGUST 17-20, 1992 (LIVERMORE, CALIFORNIA)

SAN FRANCISCO DOE

Please briefly describe how your expectations of this course were or were not met.

Very well.

Gave me a good overall knowledge.

I did not receive enough information or DOE interpretations of OSHA, or what I hoped hard copy of DOE decisions and requirements.

In general this was an excellent course. A lot of material was covered in a relatively short time frame. I would like to have seen some underground construction covered. This course helped me be able to find the appropriate regulations to cite violations.

Familiarizing myself with the construction standards which were met.

Expectations met.

Expectations were met in that I now better understand OSHA standards and how to look them up and apply them to construction activities.

Fully met my expectations.

Expectations were met. I am no's much more knowledgeable about safety conditions on construction sites.

Expectations were met.

The most helpful topics covered or activities presented in this course were:

Subparts C, E, H, I, J, L, M, N, Q, R, T, D. Just about every subpart.

Scaffolding, HAZCOM.

A. 1 


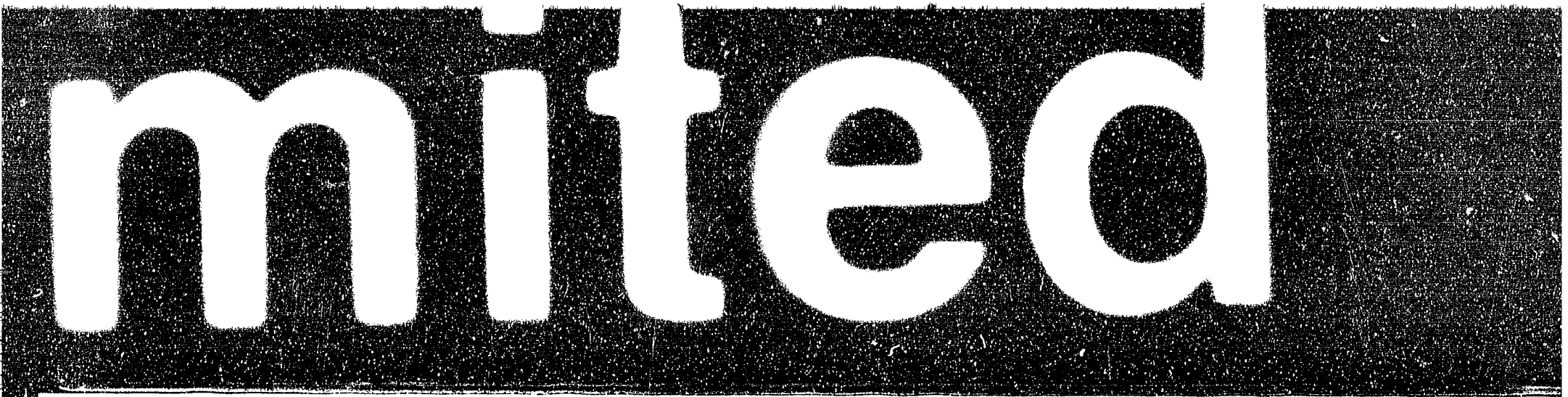

Concrete/masonry work, PPE, Steel erection and fire protection. The handout of "Most Frequent Cited Violations" was very helpful.

\section{Exercises.}

Scaffolding and handling materials and equipment.

Concrete and steel construction.

Overview, how to use the construction industry standards.

Scaffolding, toois, electrical, and fire.

Hands-on evaluation outside.

The least helpful things discussed or sule were:

Interpretations from instructor who ffers his opinion in such a way that it comes out as OSHA rules. $5(\mathrm{a})(1)$ is not a catch all!! It becomes a serious point of adjustment between DOE and Prime contractor. Bring more support documentation.

All topics were helpful.

Ladders - movie was too basic and slapstick; could have used the time in other areas by covering ladders quicker.

Rollover.

Steel erection.

More emphasis should be given to:

Backing up opinions with code sections.

DOE citations and findings. How to deal with it. Information on corrective action to convince prime contractors.

Identifying where in the manuals the type being covered were located. It would be very beneficial to supply students with "check lists" of items to look for during inspections in the various areas.

Emphas is okay.

Electrical section.

Okay.

How to spot the most obvious hazards - with examples. Hands-on. 
Less emphasis should be given to:

Routine ladder use since it is part of th 1910 course.

Slides.

What specific suggestions do you have for improving future sessions? Doing quite well.

Use slides instead of overhead. Overhead is difficult to see. Less interruption and more fact.

More "hands on" exercises like the scaffolding visit we happened to luck out with.

Sessions were okay.

Get a better laser pointer. Keep all material related to one subject area together in i.e., use two volumes but combine course material and handouts and split topics/subparts between the volumes.

On first day, only, kind of slow and disorganized start. 1 and $1 / 2$ hours could have been better used.

- ew graphs and equipment needs improvement.

Additional field work to identify hazards.

Other materials to supplement or substitute for the provided handouts? DOE order 5480.9, and other documents from DOE. I am interested in most stringent rules DOE requires. Is there a DOE inspection manual?

Checklists that can be used during inspection. It would also be very helpful if other standards or regulations (i.e., ANSI, NFPA, etc.) were reformed when 1926 topics are covered.

Copy of 5480.9 .

Daily schedule/timing of activities, worktime?

okay.

Good as is!

Adequate.

Scheduling/timing was sufficient.

Good distribution. 
Very good.

Facilities/training room arrangements?

Marginal.

Okay.

The Holiday Inn was a disgrace. One toilet broke for 2 and $1 / 2$ days (men's room had 2 and it became difficult with all the use at breaks). Aunts were everywhere and insect spray was sued without warning. Tables too small, chairs poor, $y$. small for videos.

I know it's not your fault, but the hotel has to go. Need better facilities.

The biggest problem was the small tables and the uncomfortable chairs. The lighting was not feasible.

Okay, could have been held closer to DOE/SF (i.e., Oakland area).

Bigger tables needed.

Bad! Try another site next time.

Fair, not enough table space, no waste basket.

Coffee, etc. would have been nice.

What other types of safety training courses would you like to see available?

CAL OSHA.

How DOE thinks, for safety and Q.A. people.

More in-depth courses for specific topics covered in this course to include "hands-on" or field visits.

Radiation, DOT.

\section{Any further comments?}

This is a very usefur course, handled very well despite the volume of information that the subject entialls.

Video tape classes and offer copies for review. Also instructions can see how they are doing and become more polished.

I would have liked to have seen more cross reference to DOE orders.

It was sometimes hard to keep track of where we were. Why not go in numerical order! 
APPENDIX B

TRAINEE EVALUATION FORM

A. 6 
Please evaluate various features of the course you have just completed. The information you provide here will be combined with that from other attendees and summarized for the sponsor, the U.S. Department of Energy. Results from this evaluation will be used to improve this course.

\section{Course Content}

Strongly

Agree Agree

Neither Agreo nor Dlsagree
Strongly Disagreo

Overall, as a result of this course I believe that I:

\begin{abstract}
developed specific skills and competencies in
occupational safety compliance that I can use on the job. ...

gained a greater understanding of 29 CFR 1926, Safety ......

and Health Regulations for Construction

gained factual knowledge about Foderal safety and health

i. irym requirements related to Construction
\end{abstract}

. .5

4

compliance knowledge gained from this course

will make work environments safer. .5

would recommend this course to others. .5

4

Strongty

Testing Materials

4

4

4

The final test was a good measure of the

knowledge gained in the course.
Agreo Agree
Neither Agree nor Disagree

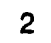

2

2

2

2

$\begin{array}{lll}3 & 2 & 1\end{array}$

\section{Toptc Areas}

Please evaluate each topic area using the 5-point scale below.
5 Excellent
4 Very Good
3 Good
2 Satisfactory
1 Unsatisfactory

Content

Instructor

Introduction to OSH/DOE Safety and Health Programs

$\begin{array}{lllll}. .5 & 4 & 3 & 2 & 1\end{array}$

General Interpretations/Recordkeeping (OSH 200 Form)

$\begin{array}{lllll}.5 & 4 & 3 & 2 & 1\end{array}$

General Safety and Health Provisions

$\begin{array}{lllll}5 & 4 & 3 & 2 & 1\end{array}$

Scaffolding

$\begin{array}{lllll}.5 & 4 & 3 & 2 & 1 \\ .5 & 4 & 3 & 2 & 1\end{array}$

Floor and Wall Openings

Ladders

Electrical

Power Transmission and Distribution (Optional Section)

Materials Handling, Storage, Use and Disposal ....

Cranes, Derricks, Hoists, Elevators and Conveyors

Motor Vehicles, Mechanized Equipment and Marine Operations .5

Rollover Protective Structures, Overhead Protection 
Welding and Cutting $\begin{array}{lllll}.5 & 4 & 3 & 2 & 1\end{array}$

Concrete and Masonry Construction ..........................................5 $4 \begin{array}{lllll}3 & 4 & 1\end{array}$

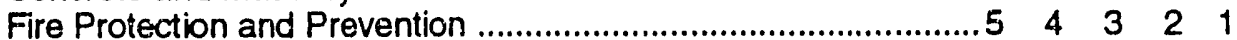

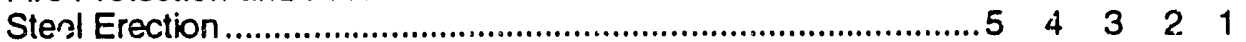

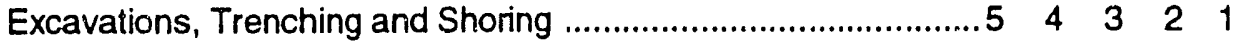

Underground Construction, Caisson, Cofferdams, and

Compressed Air (Optional Section)

$\begin{array}{lllll}.5 & 4 & 3 & 2 & 1\end{array}$

Demolition (Optional Section)

Blasting and the Use of Explosives (Optional Section)

Occupational Health and Environmental ConirolHazMat ....

Personal Protective Equipment

Signs, Signals and Barricades .....

1. Please briefiy describe how your expectations of this course were or were not met.

2. The most helpful topics covered or activities presented in this course were:

3. The least helpful topics or activities in this course were:

4. More emphasis should be given to:

5. Less emphasis should be given to:

6. What specific suggestions do you have for improving future sessions?

7. Other materials to supplement or substitute for the provided handouts?

8. Daily schedule/timing of activities, worktime?

9. Facilities/training room arrangements?

10. What other types of safety training courses would you like to see available?

11. Any further comments?

12. Overall rating: Based on your comments above, please rate the course on a 5-point scale by circling the number of your choice.

5 Excellent 4 Very Good 3 Good 2 Gathefactory 1 Unsattsfactory 


\section{DISTRIBUTION}

No. of

Copies

OFFSITE

12 DOE/Office of Scientific and Technical Information

R. E. Gibbs

Office of Safety and Quality Programs

U.S. Department of Energy

19901 Germantown Rd.

Germantown, MD 20874

G. R. Florczak

U.S. Department of Energy

EH 31.2

19901 Germantown Rd.

Germantown, MD 20874

Bernice Pelicas

San Francisco DOE

1333 Broadway

Oakland, CA 94612

Peter Cucuz

909 W. Gartner Rd.

Naperville, IL 60540
No. of

Copies

ONSITE

DOE Richland Field office

P. W. Kruger

13 Pacific Northwest Laboratory

H. N. Bowers

E. C. Handwerk

M. A. Leckband (5)

Publishing Coordination

Technical Report Files (5) 

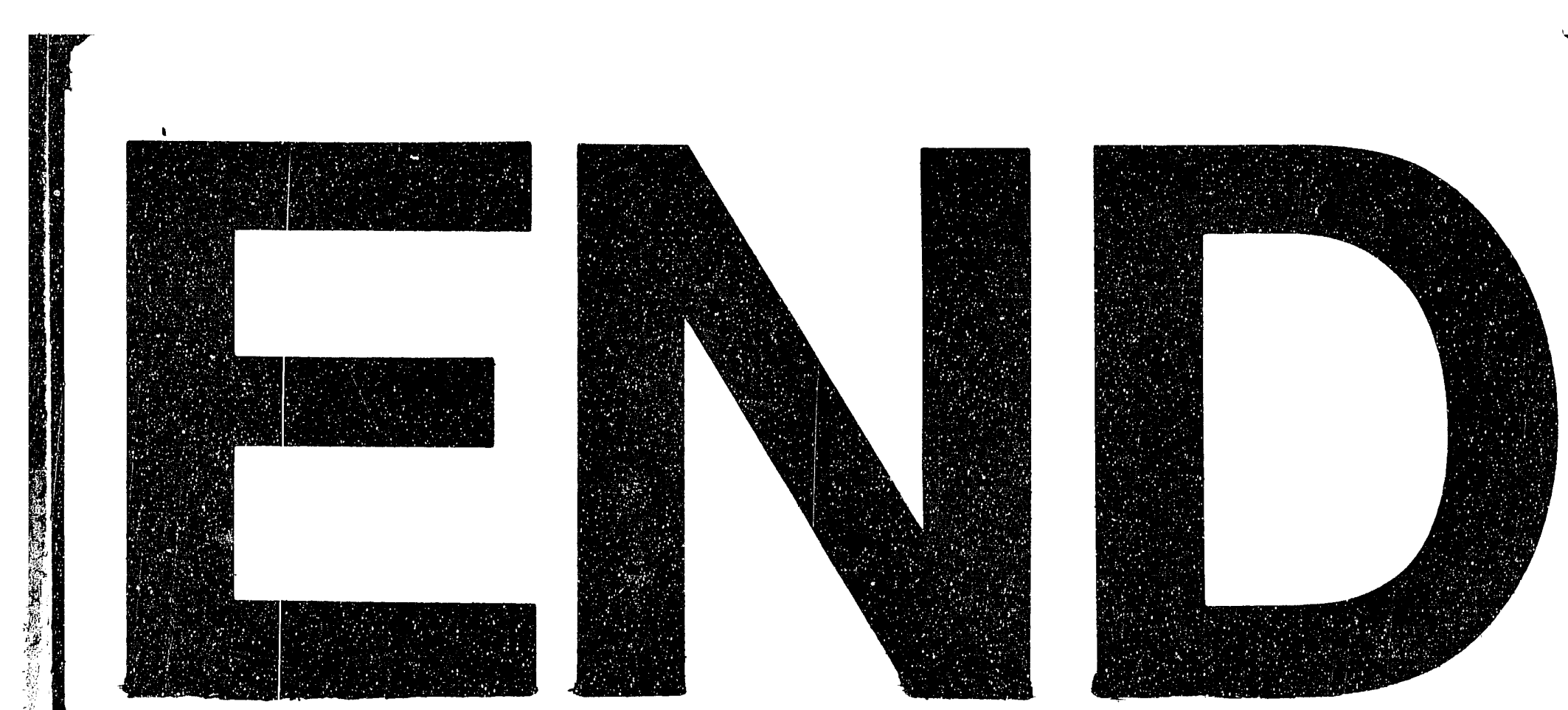

h a ing a
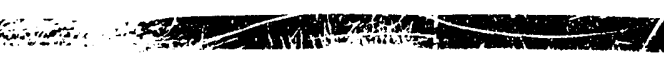

Thenention
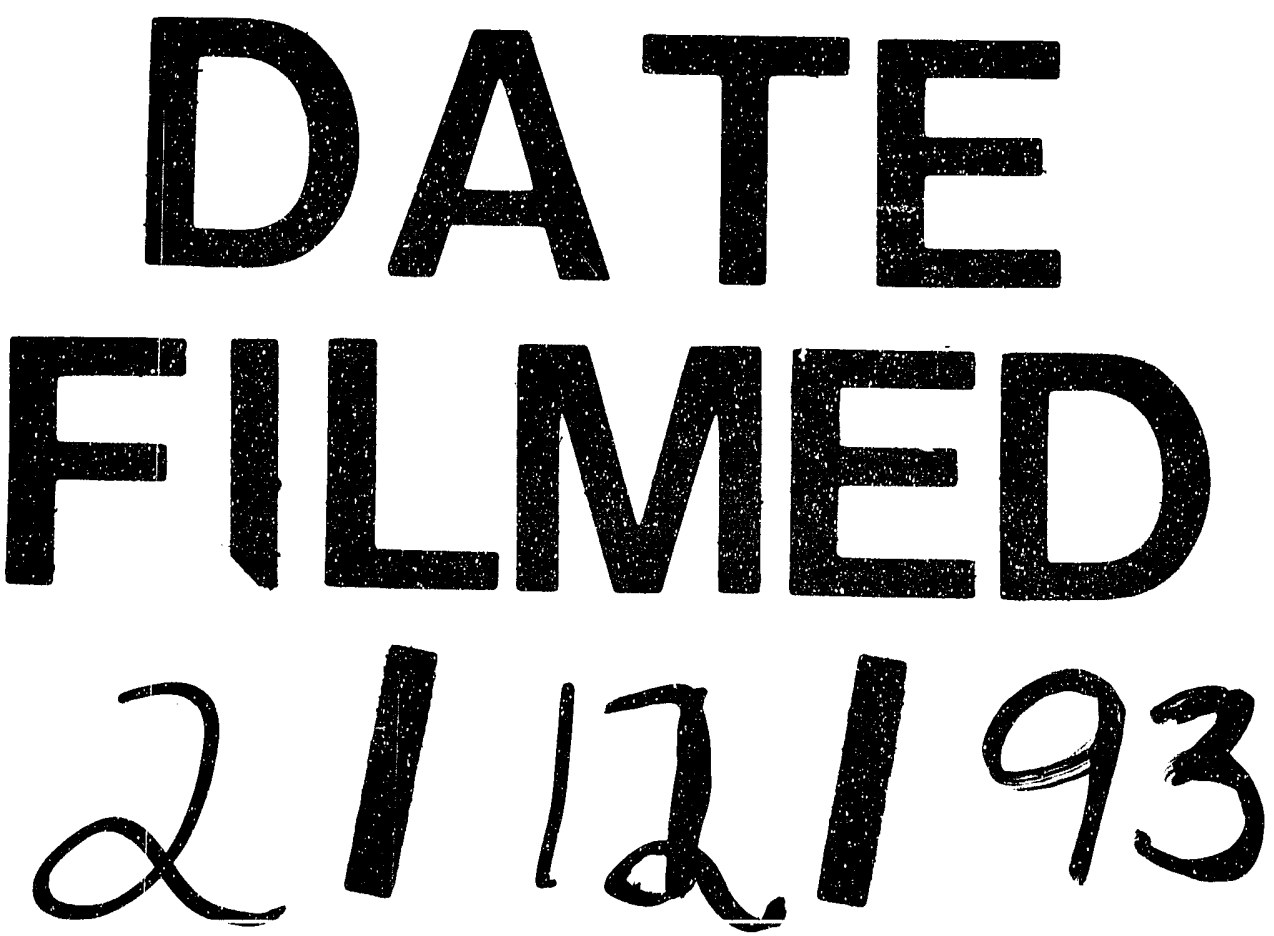
